ISSN 0258-7122

Bangladesh J. Agril. Res. 36(2) : 333-350, June 2011

\title{
IMPACT OF MICRO-FINANCE ON THE DEVELOPMENT OF STREE SHAKTI GROUP MEMBERS
}

\author{
K. V. BHAVYA ${ }^{1}$ AND K. B. UMESH ${ }^{2}$
}

\begin{abstract}
Micro- finance helps the rural poor to improve their living standards and fulfill their credit needs. Stree Shakti Groups (SSGs) are new innovation in the field of rural economic development, to finance the rural women and also to satisfy their credit needs. This study mainly focuses on the impact of micro-finance on the development of SSG members. The study was undertaken in Doddaballapura taluk of Bangalore rural district of Karnataka state, India and the required data were collected from 100 SSG members and 30 non-SSG members. It was found that the number of income generating activities taken up by SSG members (five) was higher compared to non-SSG members (three) and the income generated from these activities was also higher compared to non-SSG members. There was significant growth in the amount of loan borrowed, repayment and savings over time among SSG members. SSG finance substantially enhanced employment opportunities for members compared to non-members, which led to improved income and living standard of members. Since SSGs play a major role in the development of women, there is a need to encourage more number of SSGs. The study also reveals that the performance of Non Governmental Organization (NGO) promoted SSGs was much better than Government promoted SSGs. Hence, more number of NGOs must be involved in promoting SSGs covering more womenfolk.
\end{abstract}

Keywords: Micro-finance, Stree Shakti group, self help group, impact, empowerment, non governmental organization.

\section{Introduction}

As per estimates about 300 millions in India and around 1.2 billion population worldwide live in absolute poverty. They are unable to meet their most basic human needs for food, clothing, shelter and minimum health care. Since 1947, the absolute number of poor has doubled despite significant growth in agricultural production and employment through development planning in India. Rural poverty continues to pose the greatest challenge in India. India today retains the dubious distinction of having the largest number of poor people on the planet. Poverty in India is closely associated with poor population or an imbalance between population and land resources. The burden of such poverty falls heavily upon women and children.

${ }^{1}$ IMRD Fellow, Erasmus Mundas Scholar, University of Gent, Germany, ${ }^{2}$ Professor, Deptt. of Agricultural Economics, University of Agricultural Sciences, Bangalore-560 065, India. 
In the development paradigm, micro-finance has evolved as a need-based policy programme to cater to the so far neglected target groups (women, poor, rural, deprived, etc.). Its evolution is based on the concern of all developing countries for empowerment of the poor and the alleviation of poverty. Developmental organizations and policy makers have included access to credit for poor people as a major aspect of many poverty alleviation programmes. Micro- finance programmes in the recent past have become one of the most promising ways to use scarce development funds to achieve the objectives of poverty alleviation.

It has been approximately 25 years since the birth of Micro-finance with the founding of the Grameen Bank in Bangladesh by Professor Mohammad Yunus. The field has spread with the adaptation and evolution of Professor Yunus' ideas to various countries and contexts. The UN Year of Micro-credit in 2005 indicated a turning point of Micro-finance as the private sector began to take more serious interest in what has been considered the domain of NGOs (Non Governmental Organizations).

There is a wide variety of institutions in India catering, with various degrees of success, to the micro finance needs of poor families. As indicated above, they comprise of micro finance providers in the formal financial sector comprising of Commercial Banks, Regional Rural Banks and Cooperative Banks and Micro Financial Institutions comprising Non-Governmental Organizations, Non Banking Financial Companies, Cooperative Societies, Trusts and Self-Help Groups Federations.

Micro-financing has turned out to be effective strategy for formal financing agencies. Group lending minimizes the transaction cost and at the same time the members of a group can avail small loans through the group. The chances of misutilisation are minimum and there are assured repayment because of monitoring by the group thereby hundred per cent repayment of loan could be achieved. The group concept has enabled the rural poor to develop the habit of savings. Thus, the whole programme has been made customer-friendly. Further, it has its own impact on poverty alleviation and women empowerment. Thus, micro- financing programme targeting rural women has led to their empowerment in economic, social and political areas. Empowerment of women through Self Help Groups (SHGs) would lead to benefits not only to the individual woman and women groups but also for the family and community as a whole through collective action for development (Murugan and Dharmalingam, 2000). These groups have a common perception of need and an impulse towards collective action. Empowering women is not just for meeting their economic needs but also through more holistic social development. SHGs are essential vehicle for social, political and psychological empowerment: social empowerment provides access to information, knowledge and skills, and paves 
way for participation in social organizations financial resources; political empowerment enables the individual to take part in decision-making process that affects her future; psychological empowerment is demonstrated in self confidence behaviour (Narayanasamy et al., 2003). They also create awareness in bank transaction, health, hygiene and family welfare, social awareness and in legal aspects.

Self Help Group (SHG) is defined as a voluntary group valuing personal interactions and mutual aid as a means of altering or ameliorating the problems perceived as alterable, pressing and personal by most of its participants (Smith and Pillheiemer, 1983). These groups are voluntary associations of people formed to attain certain collective goals that could be economic, social or both without any political affiliation.

The SHG-bank linkage programme perhaps is the largest micro finance programme of the world now in terms of its outreach. It is an intermediate strategy that combines myriad issues of development experiences. The Micro Finance Development Fund in National Bank for Agriculture and Rural Development (NABARD) will further boost the capacity of various microfinance stakeholders including the members of SHGs.

The contribution of women in the present day business and commercial world is significant. The awareness of Bank lending and help from the Government made the rural women to think on new lines. The dependence on agriculture activities by the rural women is vanishing and the emergence of Stree Shakti Groups (SSGs) make a great change in the life of rural women. The Stree Shakti Program serves as an income generating opportunity for underprivileged women in the rural community. Due to a lack of education, skills and many cultural and social problems, which affect the communities in rural areas, families struggle to survive on a low, single income and are stuck in a continuous cycle of poverty. The women often stay home to care for the family, while the men struggle to find work as laborers. Men often spend their earnings outside the home and as a result, there is little income to care for the family, and children. Stree Shakti Program helps to create economic stability for women to meet the needs of their desperately poor families. The program aims to empower women to become income earners in their family by providing them with the resources and training for them to engage in productive activities. The women receive the full benefits of their labour and are able to produce a sustainable income to ensure proper education and health for their family and children.

Several studies have indicated that self help groups have contributed greatly in influencing participation of women in planning, implementation and monitoring activities of village level bodies, such as panchayats, zilla parishads, village comittiees and samities, and women were able to diversify their activities 
by undertaking non-farm and animal husbandry activities as a result of group formation (Rangi, 2004; Puhazhendi and Jayaraman, 1999). The income status of members has improved several times (Manimekalai and Rajeswari, 2000; Arunkumar, 2005) by taking up of micro-enterprises. Besides, there has been appreciable increase in employment generation on the group members who had undertaken income-generating activities (Puhazhendi, 2000; Sridhar, 1999). The micro-finance facility extended through groups has significantly contributed in improving their financial conditions and taking up of viable income generating activities ((Puhazhendhi and Satyasai, 2000; Pappachen, 2001; Arunkumar, 2005; Kalpana, 2002; Singh, et al., 2006). The SHGs are not only providing credit, but also empower women socially and economically. They encourage women to participate in decision-making in the household, community and local democratic sector and prepare women to take up leadership positions (Punithavathy and Eswaran, 2002).

A number of special programmes aimed at meeting the credit needs of the disadvantaged sections of the society have been implemented in the past. Over the years, special poverty alleviation, wage and self employment programmes like Jawahar Rozgar Yojana, Indira Awaz Yojana, Employment Assurance Scheme, Development of Women and Children in Rural Areas (DWCRA), Swarnjayanti Gram Swarojgar Yojana, Training of Rural Youth for Self Employment (TRYSEM), Integrated Rural Development Programme (IRDP), etc., have been implemented by the Government of India and State Governments for creation of wage and self employment opportunities. In 1992, NABARD lunched IRDP programme which was perhaps the biggest micro-credit programme of India and in the world as well. In spite of all these noble efforts, the disadvantaged section of the society could not access financial services from the formal financial systems and they had to either depend on the informal system or on themselves for their credit needs and this created the birth of 'micro finance'.

Stree Shakti Program was launched by the Directorate of Women and Child Development in Karnataka State in 2001. The programme is designed to provide special impetus to the empowerment of rural women in the State through the formation of Self Help Groups (SHGs). At present 1,40,000 self help groups have been formed in the state. 20.731 lakh women members have been organized in these groups till January 2010, and the members have saved an amount of Rs. 83525 lakhs. A total of 1,24,008 groups have availed bank loans to the extent of Rs. 1,12,559 lakhs and internal loan of Rs. 1,90,600 lakhs to take up various income generating activities. Rs.73.00 lakhs was released as incentive for 1460 groups to take up income generating activities.

With this background, the present study makes an attempt to analyze the impact of micro-finance on the development of Stree Shakti Group members. 
The specific issues which the study addresses are; the socio-economic profile of the Stree Shakti group members, the loan borrowings, repayment performance, savings, asset creation, employment generation, cost-return from income generating activities and the overall impact of micro-finance on the empowerment of women.

\section{Materials and Method}

For the study, Doddaballapura taluk of Bangalore Rural district of Karnataka state was selected by adopting purposive sampling technique as about 700 Stree Shakti Groups that are promoted by both Government and NGOs are functioning in the taluk. Further, for the selection of SSGs and the SSG member respondents and non-SSG member respondents, simple random sampling technique was followed. Of the 700 SSGs, ten SSGs were randomly selected comprising five SSGs promoted and facilitated by NGOs and the other five SSGs promoted and facilitated by Government agencies. From each SSG, ten member respondents were randomly selected for the study making a sample of 100 for the study. Besides, 30 non-member respondents were selected for the study as control to assess the impact of micro-finance on the members of SSG.

The required information from the sample respondents was collected through personal interview by the researcher with the help of structured pre-tested data schedule during 2008-09. The data on population statistics and general information of Bangalore Rural district was collected from Karnataka at a Glance, 2004-05. The information regarding SSGs was collected from Women and Child Development Department, Government of Karnataka, NGO's and Financial Institutions.

The collected data in respect of socio-economic profile, loan borrowings, repayment performance, savings, asset creation, employment generation, costreturn from income generating activities and the overall impact of micro-finance on the empowerment of women were analyzed using ratios, percentages and statistical tests to draw meaningful inferences.

\section{Results and Discussion}

Results of the study are presented under the following broad headings:

\section{Socio-economic profile of the respondents}

The selected socio-economic profile of sample respondents is given in Table 1. It could be observed that the average age of members belonging to Stree Shakti Groups (SSGs) was 40 years, while it was 42 years in case of non-SSG members and there was not much difference in the family size. In respect of education, marginally a higher (27\%) level of illiteracy was observed among non-members. 
The members belonging to backward caste and scheduled caste and tribe have constituted marginally higher proportion in non-SSG member category compared to SSG members. Correspondingly, the distribution of sample occupation-wise showed that larger proportion of non-SSG members belonged to agricultural labours (23\%). The institutional participation has also showed a poor (83\%) representation of non-SSG members. The annual income of the SSG member households was higher (Rs.1,66,374) compared to non-SSG member households (Rs. 1,31,325) though the size of land holding was marginally higher $(3.76 \mathrm{ac})$ among non-SSG members relative to SSG members $(2.93 \mathrm{ac})$. This could be due to better utilization of land resources by the SSG members who have access to technology, information, and inputs besides generating income through diversified farm and non-farm activities.

Table 1. Selected socio-economic profile of sample respondents.

\begin{tabular}{|c|c|c|c|c|c|}
\hline \multirow[b]{2}{*}{ Sl. No. } & \multirow[b]{2}{*}{ Particulars } & \multicolumn{3}{|c|}{ SSG members } & \multirow[b]{2}{*}{$\begin{array}{c}\text { Non-SSG } \\
\text { members } \\
(\text { control }) \\
(n=30)\end{array}$} \\
\hline & & $\begin{array}{c}\text { Govt. } \\
\text { promoted } \\
\text { SSG } \\
(\mathrm{n}=50)\end{array}$ & $\begin{array}{c}\text { NGO } \\
\text { promoted } \\
\text { SSG } \\
(\mathrm{n}=50)\end{array}$ & $\begin{array}{c}\text { Pooled } \\
(n=100)\end{array}$ & \\
\hline $\mathrm{A}$ & Age (years) & 42 & 38 & 40 & 42 \\
\hline \multirow[t]{6}{*}{ B } & Education (\%) & & & & \\
\hline & i) Illiterate & 24 & 18 & 21 & 27 \\
\hline & ii) Primary school & 44 & 50 & 47 & 43 \\
\hline & iii) Middle school & 20 & 24 & 22 & 27 \\
\hline & iv) High school & 10 & 08 & 09 & 03 \\
\hline & v) College & 02 & - & 01 & - \\
\hline C. & House Hold Size (No.) & 4 & 5 & 4.5 & 4 \\
\hline \multirow[t]{4}{*}{ D. } & Caste $(\%)$ & & & & \\
\hline & i) Forward caste & 28 & 36 & 32 & 20 \\
\hline & ii) Backward caste & 64 & 44 & 54 & 60 \\
\hline & iii) $\mathrm{SC} / \mathrm{ST}$ & 08 & 20 & 14 & 20 \\
\hline \multirow[t]{5}{*}{ E. } & Occupation (\%) & & & & \\
\hline & i) Agriculture & 52 & 42 & 45 & 40 \\
\hline & ii) Agril. Labours & 12 & 18 & 15 & 23 \\
\hline & iii) Agriculture \& Agril. labours & 24 & 12 & 20 & 10 \\
\hline & iv) Others & 12 & 24 & 20 & 27 \\
\hline \multirow[t]{3}{*}{$\mathrm{F}$} & Institutional participation (\%) & & & & \\
\hline & i) Non-member & 24 & 16 & 20 & 83 \\
\hline & ii) Member & 76 & 84 & 80 & 17 \\
\hline G. & Farm Size (ac) & 2.93 & 3.04 & 2.93 & 3.76 \\
\hline H. & $\begin{array}{l}\text { Annual Income } \\
\text { (Rs/annum/household) }\end{array}$ & $1,69,178$ & $1,63,573$ & $1,66,374$ & $1,31,325$ \\
\hline
\end{tabular}

Source: Field Survey, 2008-09 
Table 2. Borrowing and repayment of loans by sample respondents.

\begin{tabular}{|c|c|c|c|c|c|c|c|c|c|}
\hline \multirow{3}{*}{ Particulars } & \multirow{3}{*}{ Year } & \multicolumn{6}{|c|}{ SSG members } & \multirow{2}{*}{\multicolumn{2}{|c|}{$\begin{array}{l}\text { Non-SSG members } \\
\text { (control) } \\
(\mathrm{n}=30)\end{array}$}} \\
\hline & & \multicolumn{2}{|c|}{$\begin{array}{c}\text { Government promoted } \\
\text { SSG }(n=50)\end{array}$} & \multicolumn{2}{|c|}{$\begin{array}{l}\text { NGO promoted } \\
\text { SSG }(n=50)\end{array}$} & \multicolumn{2}{|c|}{ Pooled $(n=100)$} & & \\
\hline & & Group & $\begin{array}{c}\text { Per } \\
\text { member }\end{array}$ & Group & $\begin{array}{c}\text { Per } \\
\text { member }\end{array}$ & Group & $\begin{array}{c}\text { Per } \\
\text { member }\end{array}$ & Group & $\begin{array}{c}\text { Per } \\
\text { member }\end{array}$ \\
\hline \multirow{4}{*}{$\begin{array}{l}\text { Amount of } \\
\text { loan } \\
\text { borrowed } \\
\text { (in rupees) }\end{array}$} & $2005-06$ & 75845 & 1517 & 95500 & 1910 & 171345 & 1713.45 & 44800 & 1493.3 \\
\hline & 2006-07 & 88500 & 1770 & 162570 & 3251.4 & 251070 & 2510.7 & 55250 & 1841.6 \\
\hline & 2007-08 & 125500 & 2510 & 205780 & 4115.6 & 331280 & 3312.8 & 50625 & 1687.5 \\
\hline & $2005-06$ & $43280(57.1)$ & 865.6 & $\begin{array}{l}65285 \\
(68.4)\end{array}$ & 1305.7 & $\begin{array}{l}108565 \\
(63.4)\end{array}$ & 1085.65 & $\begin{array}{l}22600 \\
(50.4)\end{array}$ & 753.3 \\
\hline \multirow[t]{3}{*}{$\begin{array}{l}\text { Repayment } \\
\text { (in rupees) }\end{array}$} & $2006-07$ & $56850(64.2)$ & 1137 & $\begin{array}{l}145800 \\
(89.7)\end{array}$ & 2916 & $\begin{array}{l}202650 \\
(80.7)\end{array}$ & 2026.5 & $\begin{array}{l}32600 \\
(59.0)\end{array}$ & 1086.6 \\
\hline & 2007-08 & $95685(76.2)$ & 1913.7 & $\begin{array}{l}158965 \\
(77.3)\end{array}$ & 3179.3 & $\begin{array}{l}254650 \\
(79.9)\end{array}$ & 2546.5 & $\begin{array}{l}35560 \\
(70.2)\end{array}$ & 1185.3 \\
\hline & $2005-06$ & $32565(42.9)$ & 651.3 & $\begin{array}{l}30215 \\
(31.6)\end{array}$ & 604.3 & $\begin{array}{l}62780 \\
(36.6)\end{array}$ & 627.8 & $\begin{array}{l}21600 \\
(49.6)\end{array}$ & 432 \\
\hline \multirow[t]{2}{*}{$\begin{array}{l}\text { Overdue } \\
\text { (in rupees) }\end{array}$} & 2006-07 & $31650(35.8)$ & 631 & $\begin{array}{l}16770 \\
(10.3)\end{array}$ & 335.4 & $\begin{array}{l}48420 \\
(19.3)\end{array}$ & 485.2 & $\begin{array}{l}22650 \\
(41.0)\end{array}$ & 755 \\
\hline & 2007-08 & $29815(23.8)$ & 597 & $\begin{array}{l}46815 \\
(22.7)\end{array}$ & 996.3 & $\begin{array}{l}76630 \\
(20.1)\end{array}$ & 766.3 & $\begin{array}{l}15065 \\
(29.8)\end{array}$ & 502.1 \\
\hline
\end{tabular}

Source: Field survey, 2008-09 and from the records of NGOs and Financial Institutions working in the study area.

Note: Figures in parentheses indicate percentage to total amount borrowed. 


\section{Loans and repayment performance of the respondents}

The sources of borrowings for the SSG members include only from the group, whereas for non-SSG members include borrowings from financial institutions and other sources.

It could be observed that in case of Government promoted SSG (Table 2), the amount of loan borrowed increased from Rs.75845 in 2005-06 to Rs. 125500 in 2007-08. Borrowings per member also increased from Rs.1517 in 2005-06 to Rs. 2510 in 2007-08. There was a steady increase in repayment of loans during the three-year period (57.10\% to $76.20 \%)$. Correspondingly, the over dues has reduced from 42.90 percent in 2005-06 to 23.80 percent in 2007-08.

Among NGO promoted SSGs, there was increase in the loan amount borrowed from Rs. 95500 in 2005-06 to Rs. 205780 in 2007-08. Borrowings per member increased to Rs. 4115.60 in 2007-08 from Rs. 1910 during 2005-06. Repayment performance also showed an increase from 68.40 percent in 2005-06 to 77.30 percent in 2007-08. There was decline in the over dues from 31.60 per cent during 2005-06 to 22.70 percent in 2007-08.

Thus the result clearly reflects the fact that at the aggregate level, the amount borrowed per member has increased along with improved repayment performance.

In the case of non-SSGs, the amount borrowed per member showed marginal increase between 2005-06 (Rs. 1493.30) and 2007-08 (Rs. 1687.50). Though improved performance in repayment was seen, it was lower than that of SSG members. Similar pattern of borrowings and repayment performance was reported by Sridhar (1999) and Shilpashree (2004) in their studies earlier.

\section{Savings, asset creation and employment generation of the respondents}

Savings: The savings made by SSG members and non-members is given in Table 3 . It could be observed that yearly savings made by SSG members continuously increased from Rs. 1045 in 2003-04 to Rs. 2233 in 2007-08 per member at the pooled level. The savings per member was marginally higher among NGO promoted members than Government promoted SSG members. The savings per member among non-SSG members has also increased, but the magnitude of increase was less compared to SSG members. The findings reported by Palani and Selvaraj (2008) falls in line with the present findings.

Asset creation: It is evident from the result (Table 4) that the number of assets created as well as the value of assets by SSG members was more compared to non SSG members. This could be due to better access to information and training on various employment generating activities and availability of financial facility to SSG members. Similar opinion was reported by Sridhar (1999) in his study. 
Table 3. Savings by sample respondents (rupees per annum).

\begin{tabular}{|c|c|c|c|c|c|c|c|c|}
\hline \multirow{3}{*}{ Year } & \multicolumn{6}{|c|}{ SSG members } & \multirow{2}{*}{\multicolumn{2}{|c|}{$\begin{array}{l}\text { Non-SSG members } \\
\text { (control) } \\
(\mathrm{n}=30)\end{array}$}} \\
\hline & \multicolumn{2}{|c|}{$\begin{array}{l}\text { Government promoted } \\
\qquad \operatorname{SSG}(\mathrm{n}=50)\end{array}$} & \multicolumn{2}{|c|}{$\begin{array}{l}\text { NGO promoted } \\
\text { SSG }(n=50)\end{array}$} & \multicolumn{2}{|c|}{$\begin{array}{l}\text { Pooled } \\
(n=100)\end{array}$} & & \\
\hline & $\begin{array}{l}\text { Group } \\
\text { savings }\end{array}$ & $\begin{array}{l}\text { Savings } \\
\text { per } \\
\text { member }\end{array}$ & $\begin{array}{l}\text { Group } \\
\text { savings }\end{array}$ & $\begin{array}{l}\text { Savings } \\
\text { per } \\
\text { member }\end{array}$ & $\begin{array}{l}\text { Group } \\
\text { savings }\end{array}$ & $\begin{array}{l}\text { Savings } \\
\text { per } \\
\text { member }\end{array}$ & Savings & $\begin{array}{l}\text { Savings } \\
\text { per } \\
\text { member }\end{array}$ \\
\hline 2003-04 & 45255 & 905 & 59240 & 1185 & 104495 & 1045 & 22650 & 755 \\
\hline 2004-05 & $58240(28.6)$ & 1165 & $65380(10.4)$ & 1308 & $123620(18.3)$ & 1236 & $28750(26.9)$ & 958 \\
\hline $2005-06$ & $64753(11.8)$ & 1295 & $83692(28.0)$ & 1674 & $148445(20.1)$ & 1484 & $33086(15.0)$ & 1103 \\
\hline 2006-07 & $83569(29.1)$ & 1671 & $95396(14.0)$ & 1848 & $178965(20.5)$ & 1790 & $42085(27.1)$ & 1402 \\
\hline 2007-08 & $96395(15.3)$ & 1928 & $126953(33.1)$ & 2539 & $223348(24.7)$ & 2233 & $38250(-9.1)$ & 1275 \\
\hline
\end{tabular}

Field survey, 2008-09 and from the records of NGOs and Financial Institutions working in the study area.

Note: Figures in parentheses indicate percentage increase over previous year 
Table 4. Asset creation by sample respondents (cumulative as on 2007-08).

\begin{tabular}{|c|c|c|c|c|c|c|c|c|c|c|c|c|}
\hline \multirow[b]{3}{*}{ Particulars } & \multicolumn{9}{|c|}{ SSG members } & \multirow{2}{*}{\multicolumn{3}{|c|}{$\begin{array}{c}\text { Non-SSG members } \\
\text { (control) } \\
(\mathrm{n}=30)\end{array}$}} \\
\hline & \multicolumn{3}{|c|}{$\begin{array}{l}\text { Government promoted SSG } \\
\qquad(\mathrm{n}=50)\end{array}$} & \multicolumn{3}{|c|}{$\begin{array}{l}\text { NGO promoted } \\
\text { SSG }(n=50)\end{array}$} & \multicolumn{3}{|c|}{$\begin{array}{l}\text { Pooled } \\
(n=100)\end{array}$} & & & \\
\hline & No. & $\begin{array}{l}\text { SSG } \\
\text { loan } \\
\text { (Rs.) }\end{array}$ & \begin{tabular}{|c} 
Total \\
value of \\
asset \\
(Rs.)
\end{tabular} & No. & $\begin{array}{l}\text { SSG } \\
\text { loan } \\
\text { (Rs.) }\end{array}$ & $\begin{array}{c}\text { Total } \\
\text { value of } \\
\text { asset } \\
\text { (Rs.) }\end{array}$ & No. & $\begin{array}{l}\text { SSG } \\
\text { loan } \\
\text { (Rs.) }\end{array}$ & \begin{tabular}{|c} 
Total \\
value of \\
asset \\
(Rs.)
\end{tabular} & No. & $\begin{array}{l}\text { Loan } \\
\text { (Rs.) }\end{array}$ & $\begin{array}{c}\text { Total } \\
\text { value of } \\
\text { asset } \\
\text { (Rs.) }\end{array}$ \\
\hline Bore well & $\begin{array}{l}2 \\
(4)\end{array}$ & 25000 & 50000 & $\begin{array}{l}4 \\
(8)\end{array}$ & 32000 & 55000 & $\begin{array}{l}6 \\
(6)\end{array}$ & 28500 & 52500 & $\begin{array}{l}1 \\
(3.3)\end{array}$ & 15000 & 50000 \\
\hline Sprayers & $\begin{array}{l}3 \\
(6)\end{array}$ & 1500 & 3500 & $\begin{array}{l}4 \\
(8)\end{array}$ & 2000 & 3000 & $\begin{array}{l}7 \\
(7)\end{array}$ & 17500 & 3250 & - & - & - \\
\hline $\begin{array}{l}\text { Sewing } \\
\text { machine }\end{array}$ & $\begin{array}{l}6 \\
(24)\end{array}$ & 5000 & 10000 & $\begin{array}{l}7 \\
(14)\end{array}$ & 5000 & 8000 & $\begin{array}{l}13 \\
(13)\end{array}$ & 5000 & 9000 & - & - & - \\
\hline Pump set & $\begin{array}{l}12 \\
(24)\end{array}$ & 5500 & 12500 & $\begin{array}{l}15 \\
(30)\end{array}$ & 5000 & 12000 & $\begin{array}{l}27 \\
(27)\end{array}$ & 5250 & 12250 & $\begin{array}{l}2 \\
(6.6)\end{array}$ & 5000 & 12000 \\
\hline $\begin{array}{l}\text { House } \\
\text { construction/ } \\
\text { renovation }\end{array}$ & $\begin{array}{l}3 \\
(6)\end{array}$ & 20000 & 75000 & $\begin{array}{l}1 \\
(2)\end{array}$ & 15000 & 60000 & $\begin{array}{l}4 \\
(4)\end{array}$ & 17500 & 67500 & $\begin{array}{l}2 \\
(6.6)\end{array}$ & 10000 & 60000 \\
\hline
\end{tabular}

Source: Field survey, 2008-09.

Note: Figures in parentheses indicate percentage to total sample respondents. 
Employment generation: To derive the additional employment generated due to different activities, a comparison has been made between before and after availing loans and the result is presented in Table 5. In case of Government promoted SSGs, an additional employment of 50 days per annum was generated as they switched over from agricultural labour to livestock. The other important activities were tailoring ( 80 days) and flower vending (60 days). While in case of NGO promoted SSGs, the additional employment generated was 80 days per annum from laundry followed by 70 days from tailoring and 60 days from livestock. However, in case of non-SSG members, the additional employment generated from laundry was 60 days per annum followed by 50 days from livestock. Besides, the number of employment generating activities taken up by SSG members was more compared to non-SSG members. Sridhar (1999) in his study observed similar pattern of employment among respondents.

\section{Cost and returns from crops of the respondents}

The costs and returns from crops are presented in Table 6 . The results reveal that there was marginal difference in the net returns of crops across respondents. However, the return per rupee of cost under both irrigated and rainfed situations of different crops cultivated by SSG members were higher than that of non-SSG members. This may perhaps due to optimum use of farm resources by SSG members with improved managerial ability gained through SSG activities. Only SSG members had taken up grape cultivation with the financial support from SSGs and found to realize very attractive returns per rupee of cost (Rs.3.26).

Cost and returns from income generating activities of the respondents As evident from Table 7, Government promoted SSG members had taken up 5 different activities to generate income, while NGO promoted SSG members had taken up 4 activities and non-SSG members had taken up 3 activities. The net returns as well as returns per rupee of expenditure among SSG members were relatively high than that of non-SSG members. This might be due to better training and skill development programmes promoted by SSGs to its members with micro-finance facility extended to them.

\section{Impact of micro-finance on the respondents}

The impact of micro-finance is summarized in Table 8. The annual income realized and the additional employment generated was higher among SSG members compared to non-SSG members. Eighty percent of SSG members had institutional participation whereas, only 17 percent had institutional participation among non-SSG members. Involvement in decision making in respect of production and household aspects was high among SSG members (70\%) compared to non-SSG members (55\%). There was high empowerment level among SSG members in terms of social empowerment (89\%), economic empowerment (96\%) and capacity building (80\%) than non-SSG members. The results are in line with the findings reported by Savitha (2005). 
Table 6. Cost and returns (Rs. /ac) of crops among sample respondents.

\begin{tabular}{|c|c|c|c|c|c|c|c|c|c|c|c|c|c|c|c|c|}
\hline \multirow{3}{*}{ crops } & \multicolumn{12}{|c|}{ SSG members } & \multirow{2}{*}{\multicolumn{4}{|c|}{$\begin{array}{c}\text { Non-SSG members } \\
(\text { control }) \\
(\mathrm{n}=30)\end{array}$}} \\
\hline & \multicolumn{4}{|c|}{$\begin{array}{l}\text { Government promoted SSG } \\
\qquad(\mathrm{n}=50)\end{array}$} & \multicolumn{4}{|c|}{$\begin{array}{c}\text { NGO promoted SSG } \\
(\mathrm{n}=50)\end{array}$} & \multicolumn{4}{|c|}{$\begin{array}{l}\text { Pooled } \\
(\mathrm{n}=100)\end{array}$} & & & & \\
\hline & GR & $\mathrm{COC}$ & NR & $\mathrm{R} / \mathrm{C}$ & GR & $\mathrm{COC}$ & NR & $\mathrm{R} / \mathrm{C}$ & GR & $\mathrm{COC}$ & NR & $\mathrm{R} / \mathrm{C}$ & GR & $\mathrm{COC}$ & NR & $\mathrm{R} / \mathrm{C}$ \\
\hline \multicolumn{17}{|c|}{ Irrigated } \\
\hline $\begin{array}{l}\text { Finger } \\
\text { millet }\end{array}$ & 9235 & 5963 & 2805 & 1.55 & 7975 & 5982 & 1993 & 1.33 & 8605 & 5973 & 2399 & 1.44 & 6985 & 6210 & 775 & 1.12 \\
\hline Maize & 8565 & 5682 & 2883 & 1.51 & 8255 & 6445 & 1810 & 1.28 & 8410 & 6064 & 2347 & 1.39 & 7756 & 6882 & 874 & 1.13 \\
\hline $\begin{array}{l}\text { Field } \\
\text { bean }\end{array}$ & 15150 & 11960 & 3190 & 1.27 & $\mathrm{NC}$ & $\mathrm{NC}$ & $\mathrm{NC}$ & $\mathrm{NC}$ & 15150 & 11960 & 3190 & 1.27 & 14785 & 11850 & 2935 & 1.25 \\
\hline Grapes & 75044 & 23586 & 51458 & 3.18 & 74526 & 22352 & 52174 & 3.33 & 74785 & 22969 & 51816 & 3.26 & $\mathrm{NC}$ & $\mathrm{NC}$ & $\mathrm{NC}$ & $\mathrm{NC}$ \\
\hline \multicolumn{17}{|l|}{ Rainfed } \\
\hline $\begin{array}{l}\text { Finger } \\
\text { millet }\end{array}$ & 6236 & 5458 & 778 & 1.14 & 6265 & 5251 & 1014 & 1.19 & 6251 & 5355 & 507 & 1.17 & 6486 & 5865 & 621 & 1.11 \\
\hline $\begin{array}{l}\text { Field } \\
\text { bean }\end{array}$ & 7280 & 6295 & 985 & 1.16 & $\mathrm{NC}$ & $\mathrm{NC}$ & $\mathrm{NC}$ & $\mathrm{NC}$ & 7280 & 6295 & 985 & 1.16 & 5065 & 4086 & 979 & 1.24 \\
\hline $\begin{array}{l}\text { Horse } \\
\text { gram }\end{array}$ & 3556 & 2752 & 804 & 1.26 & 3425 & 2485 & 940 & 1.38 & 3491 & 2619 & 470 & 1.33 & 3387 & 2598 & 789 & 1.30 \\
\hline $\begin{array}{l}\text { Red } \\
\text { gram }\end{array}$ & $\mathrm{NC}$ & $\mathrm{NC}$ & $\mathrm{NC}$ & $\mathrm{NC}$ & 5487 & 3625 & 1862 & 1.51 & 5682 & 3785 & 931 & 1.50 & 5298 & 4045 & 1253 & 1.31 \\
\hline
\end{tabular}

Source: Field survey, 2008-09.

Note: GR-Gross Returns, COC- Cost of Cultivation, NR- Net Returns, R/C- Return per rupee of cost, NC-not cultivated. 
Table 7. Annual Cost and Returns from various income generating activities of sample respondents.

\begin{tabular}{|c|c|c|c|c|c|c|c|c|c|c|c|c|c|c|c|c|c|c|c|c|c|}
\hline \multirow{3}{*}{$\begin{array}{l}\text { SL. } \\
\text { No. }\end{array}$} & \multirow{3}{*}{ Activities } & \multicolumn{15}{|c|}{ SSG members } & \multirow{2}{*}{\multicolumn{5}{|c|}{$\begin{array}{c}\text { Non-SSG members } \\
\text { (control) } \\
(n=30)\end{array}$}} \\
\hline & & \multicolumn{5}{|c|}{$\begin{array}{l}\text { Government promoted SSG } \\
\qquad(\mathrm{n}=50)\end{array}$} & \multicolumn{5}{|c|}{$\begin{array}{c}\text { NGO Promoted SSG } \\
(\mathrm{n}=50)\end{array}$} & \multicolumn{5}{|c|}{$\begin{array}{l}\text { Pooled } \\
(\mathrm{n}=100)\end{array}$} & & & & & \\
\hline & & No. & $\begin{array}{c}\text { GI } \\
\text { (Rs.) }\end{array}$ & $\begin{array}{c}\mathrm{TE} \\
\text { (Rs.) }\end{array}$ & \begin{tabular}{|c|}
$\mathrm{NP}$ \\
(Rs.)
\end{tabular} & $\begin{array}{l}\mathrm{R} / \mathrm{C} \\
\text { (Rs.) }\end{array}$ & No. & $\begin{array}{c}\text { GI } \\
\text { (Rs.) }\end{array}$ & $\begin{array}{c}\mathrm{TE} \\
\text { (Rs.) }\end{array}$ & \begin{tabular}{|c|} 
NP \\
(Rs.)
\end{tabular} & \begin{tabular}{|l|}
$\mathrm{R} / \mathrm{C}$ \\
(Rs.)
\end{tabular} & No. & $\begin{array}{c}\text { GI } \\
\text { (Rs.) }\end{array}$ & $\begin{array}{c}\mathrm{TE} \\
\text { (Rs.) }\end{array}$ & \begin{tabular}{|c|}
$\mathrm{NP}$ \\
(Rs.)
\end{tabular} & \begin{tabular}{|l|}
$\mathrm{R} / \mathrm{C}$ \\
(Rs.)
\end{tabular} & No. & $\begin{array}{c}\text { GI } \\
\text { (Rs.) }\end{array}$ & $\begin{array}{c}\mathrm{TE} \\
\text { (Rs.) }\end{array}$ & $\begin{array}{c}\mathrm{NP} \\
\text { (Rs.) }\end{array}$ & $\begin{array}{l}\mathrm{R} / \mathrm{C} \\
\text { (Rs.) }\end{array}$ \\
\hline 1 & Dairy & $\begin{array}{l}18 \\
(36)\end{array}$ & 25276 & 14826 & 10450 & 1.70 & $\begin{array}{l}16 \\
(32)\end{array}$ & 25270 & 15785 & 12395 & 1.60 & $\begin{array}{l}34 \\
(34)\end{array}$ & 26278 & 15306 & 11423 & 1.74 & $\begin{array}{l}12 \\
(40)\end{array}$ & 24687 & 14547 & 10141 & 1.70 \\
\hline 2 & $\begin{array}{l}\text { Sheep } \\
\text { and } \\
\text { goatery }\end{array}$ & $\begin{array}{l}19 \\
(38)\end{array}$ & 14695 & 6270 & 8425 & 2.34 & $\begin{array}{l}21 \\
(42)\end{array}$ & 15144 & 6476 & 8668 & 2.34 & $\begin{array}{l}40 \\
(40)\end{array}$ & 14920 & 6373 & 8567 & 2.34 & $\begin{array}{l}4 \\
(13)\end{array}$ & 13756 & 6138 & 1617 & 2.24 \\
\hline 3 & Tailoring & $\begin{array}{l}6 \\
(12)\end{array}$ & 16525 & 8575 & 7950 & 1.93 & $\begin{array}{l}7 \\
(14)\end{array}$ & 17565 & 8675 & 8890 & 2.02 & $\begin{array}{l}13 \\
(13)\end{array}$ & 17045 & 8625 & 8520 & 1.98 & - & - & - & - & - \\
\hline 4 & $\begin{array}{l}\text { Flower } \\
\text { vending }\end{array}$ & $\begin{array}{l}4 \\
(8)\end{array}$ & 14585 & 8560 & 6025 & 1.70 & - & - & - & - & - & $\begin{array}{l}4 \\
(4)\end{array}$ & 14585 & 8560 & 6025 & 1.70 & - & - & - & - & - \\
\hline 5 & Laundry & $\begin{array}{l}2 \\
(4)\end{array}$ & 8561 & 3143 & 5418 & 2.72 & $\begin{array}{l}1 \\
(2)\end{array}$ & 8648 & 3256 & 5392 & 2.66 & $\begin{array}{l}3 \\
(3)\end{array}$ & 8605 & 3200 & 5405 & 2.69 & $\begin{array}{l}1 \\
(3.3)\end{array}$ & 8561 & 3826 & 4735 & 2.24 \\
\hline
\end{tabular}

Source: Field survey, 2008-09.

Note: Figures in parentheses indicate percentage to sample size.

GI- Gross income; TE- Total expenditure; NP- Net profit; R/C- Return per rupee of cost. 
Table 8. Impact of micro-finance on income, employment and empowerment.

\begin{tabular}{|c|c|c|c|c|c|}
\hline \multirow[b]{2}{*}{ Particulars } & \multicolumn{3}{|c|}{ SSG members } & \multirow{2}{*}{$\begin{array}{c}\text { Non-SSG } \\
\text { members } \\
(\text { control }) \\
(\mathrm{n}=30)\end{array}$} & \multirow{2}{*}{$\begin{array}{c}\text { 't' } \\
\text { Statistic } \\
\text { (between } \\
\text { SSG \& non-SSG) }\end{array}$} \\
\hline & $\begin{array}{l}\text { Government } \\
\text { promoted } \\
\text { SSG }(n=50)\end{array}$ & \begin{tabular}{|c|} 
NGO \\
Promoted \\
SSG $(n=50)$
\end{tabular} & $\begin{array}{l}\text { Pooled } \\
(\mathrm{n}=100)\end{array}$ & & \\
\hline Annual Income (Rs.) & 169178 & 163570 & 166374 & 139325 & $2.18^{*}$ \\
\hline Additional employment generated (days/year) & 65 & 70 & 67.5 & 55 & $1.83^{*}$ \\
\hline $\begin{array}{l}\text { involvement in decision making - production and } \\
\text { household aspects }\end{array}$ & High $(68 \%)$ & $\begin{array}{l}\text { High } \\
(72 \%)\end{array}$ & $\begin{array}{l}\text { High } \\
(70 \%)\end{array}$ & $\begin{array}{l}\text { Low } \\
(55 \%)\end{array}$ & \\
\hline Institutional participation (\%) & 76 & 84 & 80 & 17 & \\
\hline Extension participation & High & High & High & Low & \\
\hline Level of empowerment & High & High & High & Low & \\
\hline Socialempowerment (\%) & 90 & 88 & 89 & 54 & \\
\hline Economic empowerment (\%) & 96 & 96 & 96 & 60 & \\
\hline Capacity building $(\%)$ & 72 & 88 & 80 & 44 & \\
\hline
\end{tabular}

Source: Field survey, 2008-09.

Note: Figures in parentheses indicate percentage to sample size,

$*$ indicates significant at 5 percent. 


\section{Summary and Conclusion}

In this study, an attempt was made to analyze the impact of micro-finance on the development of Stree Shakti Group (SSG) members in Doddaballapur taluk of Bangalore Rural district, Karnataka, India. The major findings of the study are summarized below:

The selected socio-economic profile of sample respondents revealed that in respect of age, family size, and education there was not much difference across members belonging to Stree Shakti Groups (SSGs) and non-SSG members. The members belonging to backward caste and scheduled caste and tribe have constituted marginally higher proportion in non-SSG member category compared to SSG members. The distribution of sample occupation-wise showed that larger proportion of non-SSG members belonged to agricultural labours (23\%). The institutional participation has also showed a poor (83\%) representation of nonSSG members. The annual income of the SSG member households was higher compared to non-SSG member households. The total amount of loan borrowed as well as borrowing per member showed a significant increase between 2005-06 and 2007-08 among SSG members. There was also a steady increase in repayment of loans during these three years period correspondingly showing a significant decline in over dues. On the contrary, in case of non-SSG members, the amount borrowed per member as well as repayment performance showed a marginal increase during this period. The magnitude of increase in savings was higher among SSG members compared to non-SSG members between 2003-04 and 2007-08. Similarly, the number of assets created as well as the value of assets by SSG members was more among SSG members compared to non-SSG members. The number of employment generating activities taken up by SSG members was more compared to non-SSG members. The members of Government promoted SSG could generate an additional employment of 50 days per annum as they switched over from agricultural labour to livestock. The other important employment generating activities taken up by them were tailoring ( 80 days) and flower vending (60 days). While the members of NGO promoted SSG could able to generate an additional employment of 80 days per annum from laundry followed by 70 days from tailoring and 60 days from livestock. However, in case of non-SSG members, the additional employment generated from laundry was 60 days per annum followed by 50 days from livestock. The costs and returns from crops revealed that the return per rupee of cost under both irrigated and rainfed situations of different crops cultivated by SSG members were higher than that of non-SSG members. The net returns as well as returns per rupee of expenditure from various income generating activities among SSG members was higher compared to non-SSG members. The analysis of impact of micro-finance on the members of SSG clearly showed that the annual income realized, the additional employment generated, institutional participation, 
involvement in decision making in respect of production and household aspects and the empowerment level in terms of social, economic and capacity building was higher among SSG members compared to non-SSG members.

\section{Conclusion}

The micro-finance programme has created a tremendous impact on the livelihood of rural masses particularly the rural women. The present study not only demonstrates the positive impact of micro-finance on the several socio-economic dimensions of rural people, it also strongly supports the findings of earlier studies. There was significant growth in amount of loan borrowed, repayment and savings among SSG members. Majority of SSG members were able to get an additional employment of 50-80 days per annum under different activities due to SSG finance. Both Government and NGO promoted SSG members made assets like borewells,, pump sets, sewing machines through SSG finance, while nonmembers created assets like borewells and pump sets by loans from different sources. The number of income generating activities taken up by SSG members (five) was higher compared to non-SSG members (three) and the income generated from these activities was also higher. The activities like dairy, tailoring, laundry, sheep and goat rearing besides crops generated substantial net returns to SSG members. Involvement in decision making and empowerment was high among SSG members.

Based on the outcome of the study the following policy implications can be drawn:

As the micro-finance programme found to create a positive impact on several socio-economic dimensions of rural people, particularly on women, there is a need to give more focus on this issue by the policy makers to use scarce development funds to achieve the objective of poverty alleviation. Since Stree Shakti Groups (SSGs) play a major role in the development of rural women in terms of increased income, savings, employment, and socio-economic empowerment, there is a need to encourage more number of SSGs linking with micro-finance with formal financial institutions. Among SSGs, as revealed by the study, the performance of NGO promoted SSGs was much better than Government promoted SSGs. Hence, more number of NGOs must be involved in promoting SSGs covering more women folk.

\section{References:}

Arunkumar, B. 2005. A critical analysis of Swa-Shakti Programme in Karnataka. MSc. (Agri.) Thesis (Unpub.), University of Agricultural Sciences, Dharwad, Karnataka India.

Kalpana, P. 2002. Devoshi: The story of a SHG cluster. Swa-Shakti Bulletin, pp. 6 1-66. 
Manimekalai, N. and Rajeswari. 2000. Empowerment of women through Self Help Groups (SHG5.). Margin 32(4): 74-87

Murugan, K.R. and B. Dharmalingam. 2000. Self help groups- A new women's movement in Tamil Nadu. Social Welfare 47(5):9-15.

Narayanaswamy, N., S. Manivel and B. Bhasker. 2003. Networking SHGs and Cooperatives-An analysis of strengths and weaknesses. Journal of Rural Development 22(3): 333-344.

Palani, E. and Selvaraj. 2008. Socio-economic empowerment of women through self-help groups. Indian Cooperative Review 45(3): 210-217

Pappachen, P.M. 2001. Women and social transformation. Kurukshetra 40(3): 19-21.

Puhazhendhi, V. and K. J. S. Satyasai. 2000. Microfinance for rural people: An impact evaluation. Microjmnance for Rural People - An Impact Evaluation 6: 75.

Puhazhendi, V. 2000. Evaluation study of SHGs in Tamil Nadu. NABARD, Mumbai, India.

Puhazhendi, V. and B. Jayaraman. 1999. Increasing women's participation and employment generation among rural poor- An approach through groups. National Bank News Review, 15(4): 5-8.

Punithavathy and R. Eswaran.2002.Mobilizing women at the grassroots. Social Welfare 49(7): 18-23.

Rangi, P. S. 2004. SHGs and social defense. Social Welfare pp.30-34.

Savitha, R. 2005. Women empowerment and decision making in Agriculture- An economic study in Mysore district, Kamataka. MSc. (Agri.) Thesis (Unpub.), University of Agricultural Sciences, Bangalore, India.

Shilpashree, K. 2004. Empowerment of women through Stree Shakti Groups (SHGs )- A socio-economic analysis in Karnataka. MSc. (Agri.) Thesis (Unpub.), University of Agricultural Sciences, Bangalore, India.

Singh, B., K.S. Suhag and K. Sanjay. 2006. Impact of micro finance through self help groups - A study of Kamal district of Haryana. Haryana J. Agron. 22(2): 156-160.

Smith, D.H. and K. Pillheimer. 1983. Self-Help Groups as social movement organizations: Social structure and social change; research in social movements, conflicts and change,Vol.5, No.2.

Sridhar, K. 1999 Self-Help Groups and Rural Finance- A study in Chitradurga district of Karnataka state. M. Sc. (Agri.) Thesis (Unpub.), University of Agricultural Sciences, Bangalore, India. 